\title{
SPATIAL AND TEMPORAL DYNAMICS OF THE VEGETATION OF COMOÉ-LÉRABA RESERVE AND ITS SURROUNDING LANDS (BURKINA FASO, WEST AFRICA)
}

\author{
Assan Gnoumou ${ }^{2}$, Eugen Rusu ${ }^{3}$, Adouabou Basile, \\ Adjima Thiombiano ${ }^{1}$
}

Key words: remote sensing, diachronic, protected area, management, plant community

\begin{abstract}
In Burkina Faso, vegetation dynamic has been more influenced by human activities. Actually, the interest is focus on protected areas, which are more green areas and the last habitat for biodiversity. Conservation and restoration require a thorough understanding of the dynamic of each protected area and its surrounding zones. This study aim to analyze Comoé-léraba protected area vegetation spatial and temporal changed. For this study, we use satellite images taking account a period of twenty years (1990-2000-2009). Then the diachronic analysis considers globally and separately the land cover situation inside the protected zone and outside in the surrounding zone. As results, the diachronic study of Comoé-Léraba vegetation revealed significant changes. Some plant communities have remained intact; others were restored inside the protected area and against others suffered a severe deterioration. The vegetation degradation occurs, around and close to the protected area. During the twenty years $14.28 \%$ of the natural vegetation has been loss, versus expanding fields and settlements. Beyond the obtained maps, an important data based is available. These results are important scientific stools which can support policy, conservationists and researchers for improving strategies of conservation in Comoé-Léraba zone.
\end{abstract}

\section{Introduction}

Investigations on canopy at a local level directly in the field are laborious, tedious and almost impossible on large scale. Often, there is subjective

\footnotetext{
1 University of Ouagadougou, Departement of plants biology and plants physiology, Ouagadougou, Burkina Faso

2 Aube Nouvelle University, Laboratory of information system, environment management and sustainable development, Ouagadougou, Burkina Faso.

${ }^{3}$ Alexandru Ion Cuza University, Faculty of Geography and Geology, Iasi, Roumania
} 
estimation of the canopy and it can vary depending on the evaluator. Direct assessment of the vegetation is also limited in time and on a small scale (Yang et al., 2012). Furthermore, remote sensing gives an alternative to quantify the biophysical elements of the land cover (Conhen et al., 2003). It allows more access to information on their previous state. Therefore, monitoring of the dynamics of vegetation in time and space, using satellite images is a valuable contribution to the management of natural resources (Leimgruber et al., 2005). This monitoring provides specific estimates of vegetation cover and the pace of deforestation. Hence, remote sensing is widely used in tropical forest study which is strongly influenced by bioclimatic and anthropogenic processes (Vaidyanathan et al, 2010). Studies in West Africa have shown that deforestation occurs at an alarming rate (Dibi et al, 2008; Ajonou et al 2010.). The vegetation of Burkina Faso is also influenced negatively by this process which leads to the regression of the canopy.

Mapping land cover from satellite images LANDSAT TM 1992 and Landsat 7 ETM +2002 has quantified the rate of deforestation in Burkina Faso (Anonymous, 2006). On average, its canopy is under an annual decrease of 110,500 ha or $4.04 \%$ per year from 1992 to 2002 (Anonymous, 2006). Reducing the rate of deforestation, would require investigations at two levels. First, a precise knowledge of the areas covered by vegetation which is lost and its rate of deforestation (Davidar et al, 2010.) and secondly, to control the causes at reduced scales. Causes at local level can vary from one location to another (Inoussa et al., 2011), as the cultures and history of local people have an impact on their activities. Satellite images are still reliable tools in the analysis of vegetation dynamics in time and space (Kanembou et al, 2009; Ajonou et al, 2010). Some survey on protected area vegetation dynamic have proved that many changes occurred particularly around protected areas (DeFries et al., 2009) and often even inside the protected area (Guinko, 1997). And this is a major concern for natural resources conservation in protected areas. Located in the extreme southwest of the country, the classified forest and partial faunal reserve of Comoé-Léraba (Comoé-Léraba reserve) is widely influenced by local populations who are mainly farmers. This area is facing to rapid population growth because of its enormous potential climate-related characteristics compared to other regions of the country. The expansion of cultivated areas is significant; leading to the vegetation loss with biodiversity general. It is then necessary to provide reliable scientific information's which should be a better guide to define methods for these plants communities' management and sustainable used.

This research aims to analyze the spatial and temporal dynamics of the vegetation; the land used of the reserve Comoé-Léraba with its surrounding 
zones (10 kilometers around the protected area) using satellite images of three different periods with two gaps of ten years (1990-2009). The specific objectives are:

- to analyze the dynamics of land use inside the protected area and outside in its surrounding land;

- to produce land use maps which can be used as a tool for decision making in the context of the management and conservation of natural resources in the protected area.

\section{Study site}

The classified forest and partial faunal reserve of Comoé-Léraba is located in the South-western part of Burkina Faso (figure 1); between the latitudes $10^{\circ} 2^{\prime}$ and $9^{\circ} 31^{\prime} \mathrm{N}$ and the longitudes $4^{\circ} 55^{\prime}$ and $4^{\circ} 13^{\prime} \mathrm{W}$. It was established

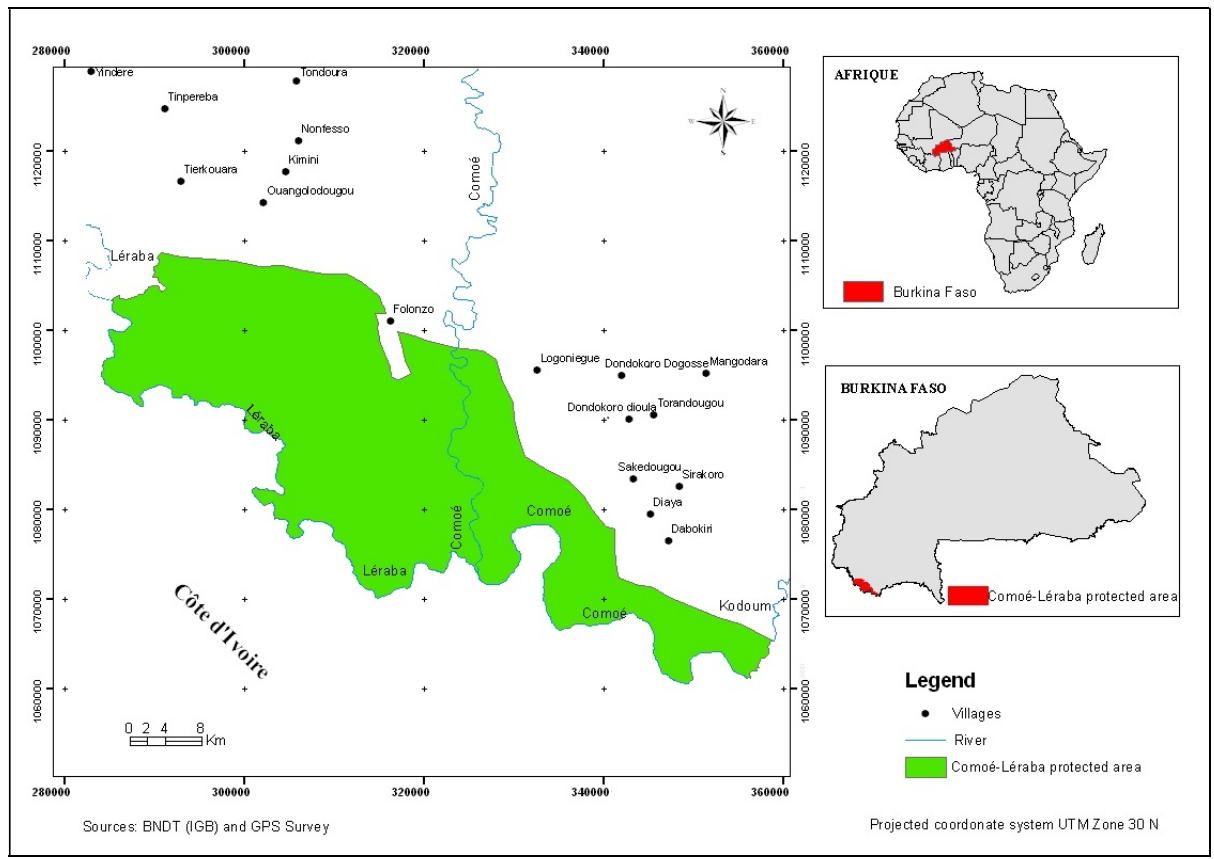

Figure 1: Map of the classified forest and partial faunal reserve of Comoé-Léraba

from two existing classified forests (Diéfoula and Logoniégué) in 2001. It covers 125000 ha. The Comoé-Léraba reserve belongs to the category IV of IUCN protected areas (IUCN, 1994) and also is a Ramsar site since 2009 (www.ramsar.org) mainly due to the 2 permanent rivers (Comoé and Léraba) which cross the reserve. The reserve is managed by the local association 
“AGEREF" (Comoé-Léraba classified forest and partial faunal reserve's intervillage association of natural resource management). Hunting and ecotourism are permitted under a forester agreement in a specific period of each year during the dry season. Land use pressure is high in the cultivation zone surrounding the reserve. Indeed the conservation of this protected area is sustained by the integrated management based on local participation (AGEREF). After 13 years, positive results have been obtained, according to the spatio-temporal dynamic survey of the protected area and its surrounding zones (Gnoumou, 2013).

\section{Materials and methods}

\section{Satellite data}

The images have been chosen according to our objectives by covering throughout the reserve and its surrounding zones.Two types of images were used namely Landsat TM, ETM ETM + or for the periods 1990 and 2000. The average spatial resolution is $30 \mathrm{~m}$. Then ASTER image for the period 2009 with $15 \mathrm{~m}$ spatial resolution. The period of shot of all images corresponds to the month of November.

\section{Vector data used and images processing}

Then the national geographic institution data base has been used for some spatial important information's; firstly to check already made the 2009 ASTER image. Moreover, they were used in superposition with the results of the processed images; such as a part of occupation, in the cases of the river and road networks and localities.

Images (1990, 2000 and 2009) processing for data base development, took place at the end of the identification of land used classes and the establishment of key of classes interpretation. GEOMATICA 9.2 PCI, software have been used in the image processing.

For a better spatial understanding of the dynamics of land use in the study area from 1990 to 2009, our analysis will focus first on the space of the classified forest of Comoé-Léraba and secondly on the land located in the band of $10 \mathrm{~km}$ around it.

Indicators for analyzing which changed over time in terms of land cover units are the size and the attribute. These indicators are obtained from the automatic crossing of land tenure data. The sequences are: 1990-2000, 20002009 and 1990-2009. 


\section{Results}

1. Analysis of changes in occupancy units' inside the classified forest of Comoé-Léraba

During the period (1990-2009), the evolution of different land cover units within the reserve Comoé-Léraba is as follows:

The unit composed of dense dry forest and riparian forest: in 1990, this unit covered $6.08 \%$ of the total classified forest area; in 2000, it has increased, or $9.27 \%$ of the classified forest area and in 2009 , it recorded a slight decline to occupy $8.99 \%$ of the area;

-The unit composed of woodland and woodland savanna: it was respectively 33. 98\% of the classified' forest area in 1990 and $43.09 \%$ of latter in 2000. This unit has declined in 2009 and occupying $42.76 \%$ of the total area of the reserve;

-Tree savannas: they have also evolved as the previous land cover units. The unit covered $33.34 \%$ of the forest area in 1990 , before knowing an expansion in 2000, occupying $39.24 \%$ of this area. It recorded a slight decrease of its size in 2009 and accounted for only $38.87 \%$ of the classified forest area;

-Shrubs-Savanna: they have seen a significant decline between 1990 and 2000 , respectively, $22.47 \%$ and $6.87 \%$ of the total forest area. In 2009 its area increases to occupy the proportion of $7.3 \%$ of the forest;

-Field-settlement: an area equal to $1.54 \%$ of the classified forest area in 1990 , this unit has been reduced in its size in 2000 , representing $0.23 \%$ of the classified forest. But in 2009 we noticed the emergence of new growing areas causing an increase in area $(0.70 \%$ of the classified forest area).

-Ground: their size remained the same in 1990 and 2000 is $0.79 \%$ of the total area of the study area. In 2009 there was a significantly lower coverage of the ground that felt to $0.78 \%$.

- Stretch of water : their area also remained constant with the proportion of $0.52 \%$ of the total classified forest area in 1990 and 2000 The scope of these stretch of water a value of $0.50 \%$ decreased significantly from $0.02 \%$ in 2009 .

\subsection{The main evolutionary trends of land-cover units' inside the protected area}

Based on interpretation of satellite images, it had a significant change in areas of almost all units of ten land occupation (10) years, with the exception of the unit areas of field-settlement a decline. Indeed, the space occupied by field areas, abandoned as a result of the amendment limits the protected and changes its status area, have evolved into shrubs-savanna or Tree savannas. Similarly, other units have also evolved into units of upper layer (eg shrubssavannas in tree savannas, tree savannas into woodlands). This reconstruction of vegetation units of the entity, appears to be related to the management 
(government and local populations) established for the conservation of natural resources. Against by ten (10) years after, there is a small degradation of natural resources with the reduced area of vegetation units in favor of growing areas and bare surfaces. This reflects a timid return of farmers in this protected area. The resource degradation during this period may also be linked to a climate problem, because the stretch of water decreased during this period.

However, a diachronic analysis of the 20 years (1990 to 2009) reveals a trend of growth in the unit dense dry forests -riparian forests, the unity of woodlands and woodland savanna and tree savanna. This shows a reconstruction of vegetation cover in the protected area as parallel, there has been a significant loss of shrub savanna, field, settlement and open areas.

\section{Analysis of changes in occupancy units' outside the classified forest of Comoé-Léraba}

Changes in the level of land-cover units in surroundings zones are as follows:

-The unit of dense dry forest and riparian forest: occupying $6.85 \%$ of the area of land in 1990, this unit has evolved in 2000 to $9 \%$ in the same area. In 2009 the unit has been weakened and covered only $8.24 \%$ of the area of the study area.

-The unit woodland and woodland savanna: it stretched respectively $30.41 \%$ of the area studied in 1990 and $34.15 \%$ from the same area in 2000 it reached a slight decline in 2009 and occupied a proportion of $29.65 \%$.

-Tree savanna: in 1990 this unit covered $33.27 \%$ of the surface area. It recorded an increase in its surface in 2000 reaching $39.04 \%$ of the area of the surrounding land. In 2009, savannas were in regression and accounted for $33.76 \%$ of the total area studied.

-Shrubs savanna: the area of this unit recorded a decline over the years: in 1990 , it was $21.35 \%$ of the total area, and $6.35 \%$ then $5.98 \%$ respectively in 2000 and 2009.

-Field-settlement: they have not ceased to increase outside the classified forest. In a proportion of $7.27 \%$ of the total area studied in 1990, they covered $10.61 \%$ of the area in 2000 . Their area has almost doubled in 2009, reaching $21.55 \%$ of the area of the surrounding zones.

-Ground: their area which was $0.54 \%$ of the surrounding zones has remained unchanged throughout the study periods.

- Stretch of water: the surface stretch of water also remained constant during the study periods: in 1990 and 2000 , it covered $0.30 \%$ of the total area studied and in 2009 it was $0.29 \%$ of the same area. 


\subsection{The main evolutionary trends of land use units in territories}

The inter-period 1990 and 2000 analysis reveals an increase in the area of certain land-cover units. Vegetation units having recorded an increase in their areas are dense dry forest and riparian forest, woodland and woodland savanna, and tree savanna. This could be the result of a reconstruction of forest resources in these units. But, there is an increased area of field and settlement corresponding to the loss of natural vegetation. Indeed, in contrast to previous vegetation units above, that of shrubs woodlands has declined dramatically during the same period. These types of plant communities were certainly very popular for agriculture. In the decade (2000-2009), we observe the opposite effect, because all units have recorded a decline in their proportion in terms of area with an exception of field and settlement areas who continue to spread.

Thus the overall synthesis of the 20-year period (1990-2000) shows a significant increase in the proportion of agricultural zones. There has also been a slight recovery of two units which are those of dense dry forest and riparian forest, then tree savanna. But, only the increase of the unit of dense dry forest and riparian forest can be considered as a gain in natural resources. As tree savannas could come from the degradation of higher vegetation units (woodlands and woodlands savanna). Regarding units of woodland and woodland savanna, as well as the shrubs woodlands, their areas trends are reducing. 


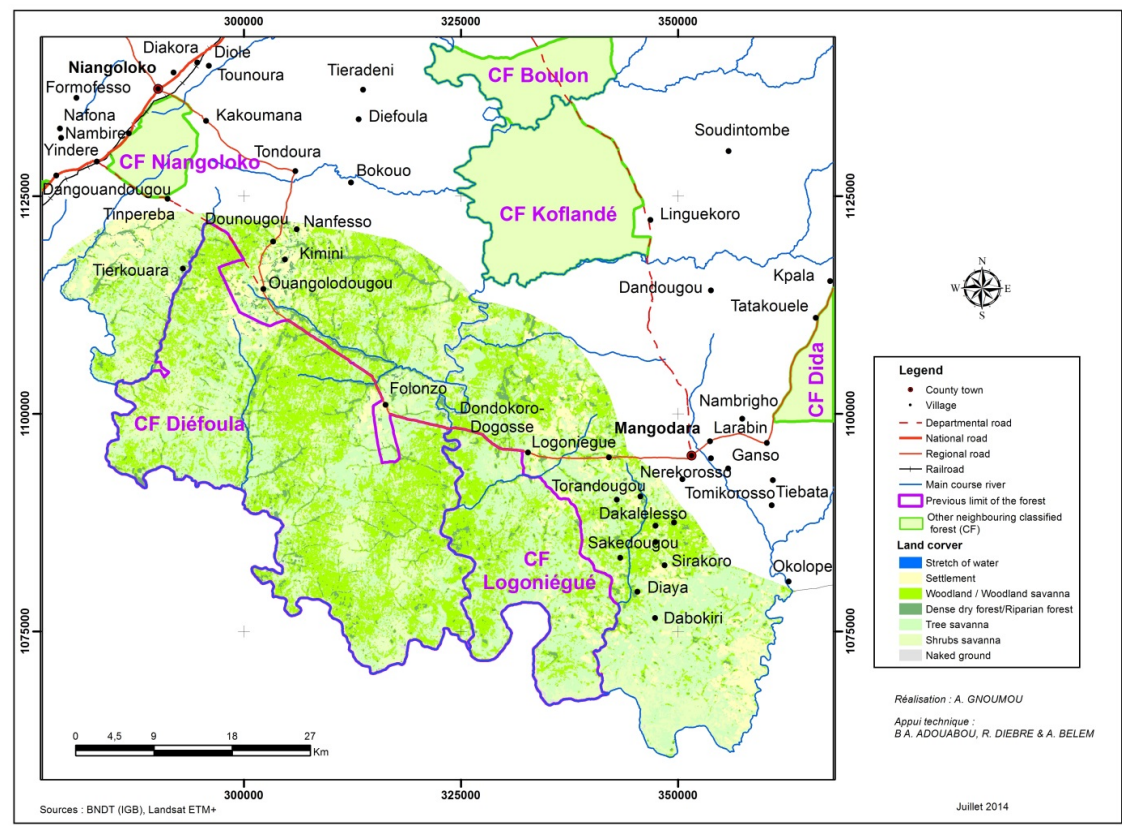

Fig 2: Land cover map in 1990 (protected area and surrounding area)

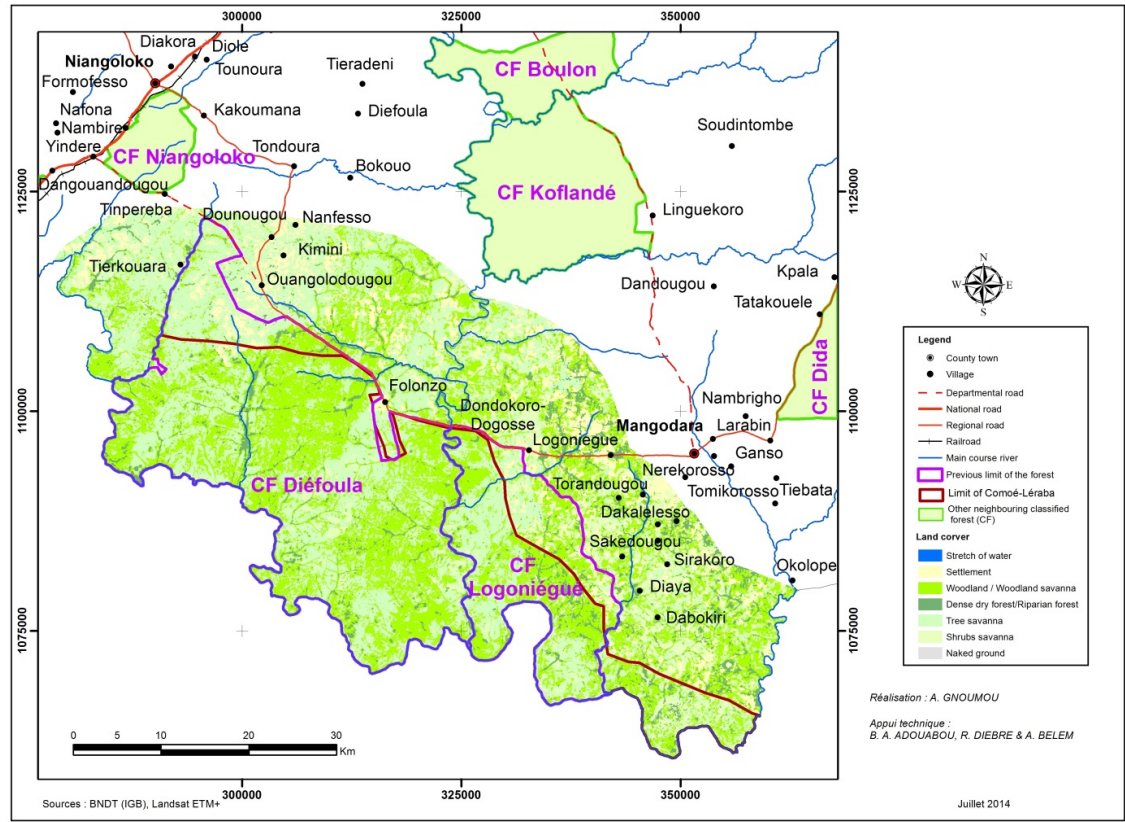

Figure 3: Land cover map in 2000 (protected area and surrounding area) 


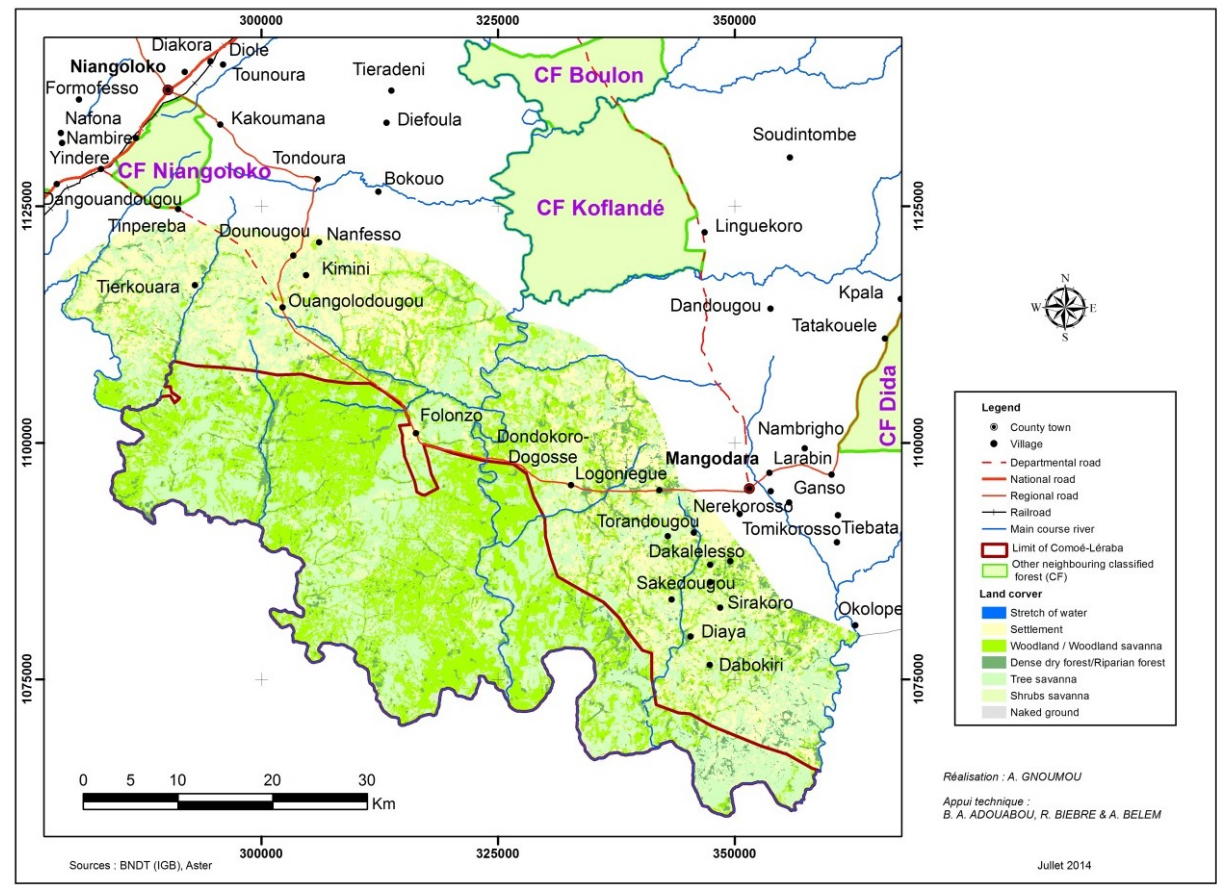

Figure 4: Land cover map in 2009 (protected area and surrounding area)

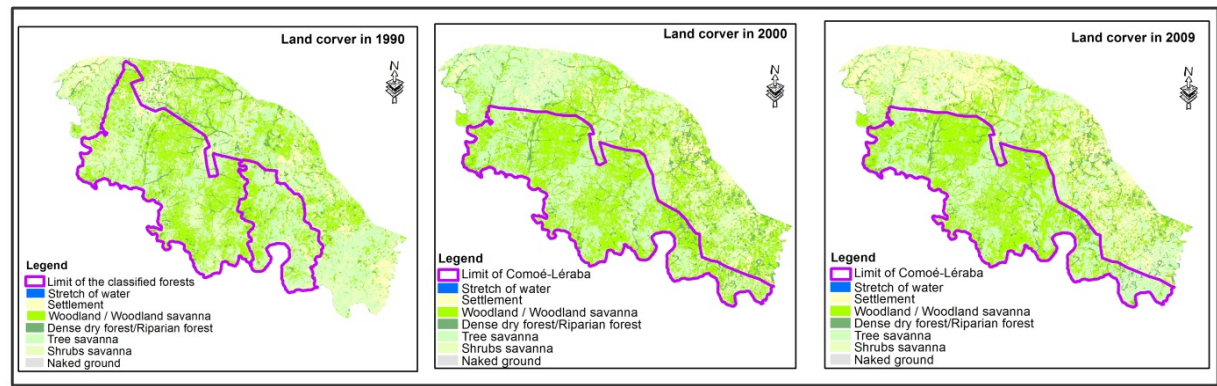

Figure 5: Maps of land cover evolution in 1990, 2000 and 2009.

\section{Discussion}

1. Global trend of the natural environment between 1990 and 2009

Strong pressure was exerted on vegetation classified forests Diefoula and Logoniégué despite their protected area status. Indeed, an area of 3194.51 ha was occupied by the fields and settlement. One of the burdens of conservation is fraudulent and illegal exploitation of natural resources that we are trying to 
protect (Gavin et al., 2010). Several approaches to conservation have been adopted by the managers of protected areas to address this practice. But since these twenty (20) years, the participatory approach seems to be the most appropriate solution (Mengue Medou-2002) in protected developing country areas. The combined effort of the government and local communities around the resource management of the protected area has been satisfactory in view of the results obtained. In general, this study reveals a substantial decline in fields and settlement as shrubs woodland inside the reserve. It means a good recovery. However, it is necessary to be careful because there is tentatively recovering of field in 2009 in the buffer zones. The most coveted plant communities have been reduced faster and faster in surrounding zones. And farmers may try again to move to the protected area to conquer new lands.

\section{The causes of the evolution of plant communities units}

2.1. Impact of some projects and AGEREF in the natural resources conservation

The main objectives of the projects (GEPRENAF, PAGEN) was to fight against uncontrolled deforestation has resulted in soil depletion, desertification. The approach of these projects strategy and especially the AGEREF in conservation was full accountability of local communities in the management of natural resources. This approach then allowed all levels of the local populations to take part in-depth analysis of potentials and constraints for the development of villages, before committing to it. But certainly in 1996 already a nucleus of people did not notice this strategy of management of the protected or the new boundaries area to be redefined, or possibly that some accepted and do not feel the benefits directly in improving their quality of life. All these reasons could explain the appearance of field areas in the buffer zone of Ouangolodougou and also beyond the limits in the area Massadéyirikôrô. But the sizes of these new areas of cultivation and fallow non-blended currently have a negligible area $(0.70 \%$ Comoé-Léraba). However this is not to overlook, it is the changing attitudes of a layer of local population, or failure to comply with strict rules already known to all the inhabitants of the villages involved. This attitude could lead to the situation where vegetation dynamics was strongly influenced by the farmers. It could be also that they do not perceive the extent of damage they cause or are already feeling the consequences, but they cannot control factors such as population growth and climate change. And this could seriously affect the sustainable conservation of this protected area. 


\section{Causes regression of plant communities units}

3.1. Influence of anthropogenic pressure on the vegetation dynamics of the protected area and its surrounding zones

Fields and settlement are growing faster and faster in the surrounding zones. The analysis of the dynamics of land-cover units also clearly shows the change of a proportion of each unit of plant community in field. Anthropogenic pressure on the canopy is characterized by the uncontrolled exploitation of plant communities. It is characterized by the practice of extensive agriculture (Hertel et al., 2009) based on bush burning (clearing vegetation, selective species and unfair cuts ...), late fires caused by poaching, trampling during grazing (Inoussa et al. 2011; Okayasu et al., 2010), gathering and harvesting threatening the survival of many species hence whose of plant communities. These practices certainly existed in the past but people managed to live in harmony with nature. But nowadays the population growth (Munsi et al., 2010) and trends in livestock pose a threat to the natural environment (Kanembou et al., 2009). In 1985, the study area had 8482 inhabitants. This population move to 16,148 in 1996 (according to the general census of the population), then the rate of increase provided 36,509 inhabitants in 2010 (Anonymous, 2000). In addition Ivorian crisis (2002-2003) led to a wave immigrations Côte d'Ivoire to many villages AGEREF as being among the closest communities in Burkina Faso. However, the area also hosts Burkinabe from other parts of the country in search of new farmland. They are usually installed in the villages or settlements. The main cash crop in the region is yam. For yam cultivation, farmers prefer new community of woodland or savanna woodlands. Shrubs savanna or tree savanna on sandy soil texture are highly sought for growing peanuts and sesame. However, we cannot lose sight of the fact that excessive use of these plant formations can lead to their scarcity or their long-term loss (Kanembou et al., 2009). The canopy can also deteriorate under the pressure of pastures (Hamandawana, 2011). Farming is practiced in the area by Fulani installed in almost all villages AGEREF or transit with the cattle towards the Côte d'Ivoire. Thus, livestock grazing natural regeneration (seedlings and young plants) of several woody species (Afzelia africana, Khaya senegalensis, Uvaria chamea, Pterocarpus erinaceus, ...etc.) thus preventing the survival of their populations.

\subsection{Influence of climate changed on the vegetation dynamics of the protected area and its surrounding zones}

The decline in Stretch of water was found inside the protected as well as in the surrounding area, these last twenty (20) years. This could be explained from the rainfall data and weather from Niangoloko and Mangodara. There is a decrease in the amount of rainfall in the last 10 years compared to previous. 
Similarly, these last 5 years, the month of November which correspond to the period of different satellite images are no longer wet. At this declined and poor distribution of rainfall over time, adds global warming (IPCC, 2007). Then the climate is resulting in rapid evaporation of water. According to the work of Millogo (2001), these climatic conditions are observed in Burkina Faso for nearly 40 years ago. They have resulted in the frequent droughts that occurred $(1968,1973$ and 1984) and also the climate is showed by the step back towards the south of the isohyets 600 and 900 in 30 years (Millogo, 2001). The impact of climate is more general and then cross-border (Hannah, 2009). Climate affects the vegetation in the study area. Climatic variations are cited among the factors that induce the disappearance of plant species (Da, 2010). This then leads to the disappearance strong degradation of plant and regression of vegetation resources. This could explain the natural regression of certain formations in the protected area, as the case of the unity of riparian forests and dense dry forests. We have seen the death and falling trees of some dense dry forest such as Anogeissus leiocarpa and Guibourtia copallifera. In rare cases, the entire island is destroyed without the intervention of human. There is also the fall of large trees (Dialium guineensis) along the riparian. This drop is caused by a surge of rainwater stagnating longer than before. The impact of thunderbolt on the destruction of many large trees was remarkable on some woodland of Isoberlinia doka in 2008.

\section{Conclusions}

The diachronic study of Comoé-Léraba reserve land cover and its surrounding areas revealed significant changes in the dynamics of twenty (20) years. Some plant communities have remained intact; others were restored and against others suffered a severe deterioration. The study shows that human pressure is very strong on plant resources around this protected area. And a new invasion is not spared the reserve Comoé-Léraba. The updated land cover maps allow conservationist of this protected area to locate new areas of crops and deal with these fraudulent practices within the forest. But can we find a balance between conserving biodiversity without taking into account the wellbeing of populations? So, our opinion is the control of population growth and the awakening of consciousness on the rational and efficient use of available resources, so that the overall system in which ecosystems coexist to maintain its total balance. 


\section{References}

Adjonou K., Djiwa O., Kombate Y., Kokutse A. D., Kokou K. 2010: Etude de la dynamique spatiale et structure des forêts denses sèches reliques du Togo: implications pour une gestion durable des aires protégées. Int. J. Biol. Chem. Sci. 4(1): 168-183.

Anonyme 2000 : Plan d'aménagement et de gestion de la forêt classée et réserve partielle de faune de la Comoé- Léraba, $68 \mathrm{p}$

Anonyme 2006 : Evolution de l'occupation des terres entre 1992 et 2002 au burkina faso. Deuxieme programme national de gestion des terroirs (PNGT2), Ouagadougou, $30 \mathrm{p}$.

Cohen W. B., Maiersperger T. K., Gower S. T., Turner D. P. 2003: An improved strategy for regression of biophysical variables and Landsat ETM+ data. Remote Sensing of Environment, 84: 561-571.

Da S. S. (2010): Spatial patterns of West-African plant diversity along a climatic gradient from coast to Sahel. Dissertation. University of Bonn. 131 pages.

Davidar P., Sahoo S., Mammen C.P., Acharya P., Puyravaud J-P., Arjunan M., Garrigues J.P., Roessingh K.(2010): Assessing the extentand causes of forest degradation in India:Where do we stand? Biological Conservation (143): 29372944.

DeFries R., Rovero F.,Wright P.C., Ahumada J., Andelman S. J., Brandon K., Dempewolf J., Hansen A., Hewson J., Liu J.,2009: Fromplottolandscapescale: linking tropical biodiversity measurements across spatial scales. Frontiers in Ecology and the Environment. doi:10.1890/080104.

Dibi N'da H., N'guessan K.E., Wadja M.E., Affian K. 2008: Apport de la télédétection au suivi de la déforestation dans le Parc national de la Marahoué (Côte d'Ivoire). Revue Télédétection, 8(1): 17 - 34.

Gavin M., Solomon J., Blank A. 2010: Measuring and Monitoring Illegal Use of Natural Resources. Review. Conservation Biology. Vol (24), No.1

Gnoumou A. 2013: Diversité et dynamique spatio-temporelle de la végétation et réserve partielle de faune de la Comoé-Léraba (Sud-Ouest du Burkina Faso) Thèse Unique de doctorat, Université de Ouagadougou, $183 \mathrm{p}$.

Guinko S. 1997: Caractérisation des unités de végétation et appréciation de la diversité faunique de la zone d'intervention du projet GEPRENAF. Ministère de l'environnement et de l'eau, $74 \mathrm{p}$.

Hamandawana H. 2011: The impacts of herbivory on vegetation in Moremi Game Reserve, Botswana: 1967-2001. Reg Environ Change. DOI 10.1007/s10113-0110230-0

Hannah L. 2009: A global Conservation System for Climate-Change Adaptation. Conservation Biology, Vol. 24,No.1,70-77.

Hertel D., Harteveld M.A., Leuschner C. 2009: Conversion of a tropical forest into agroforest alters the fine root-related carbon flux to the soil. Soil Biol Biochem, 41:481-490 
Inoussa M.M., Mbow C., Mahamane A., Bachmann Y., Saadou M. 2011: Dynamique spatio temporelle des forêts claires dans le Parc National du W du Niger, Afrique de l'ouest. Sécheresse 22: sec 2011.0305.

IPCC. 2007: Fourth assessment Report 2007.

IUCN. 2004: 2004 IUCN Red List of Threatened Species. Downloaded on 15 February 2006. Cambridge, UK: International Union for Nature Conservation and Natural Resources.

Kanembou L., Ambouta K. J. M., Waziri M. M. 2009: Dynamique des aires pastorales dans le département de Gouré : apport de la télédétection et du SIG. Rev. Sc. Env. Uni., Lomé (Togo). N 005. ISSB 1812-1403.

Leimgruber P., Kelly D.S., Steininger M.K., Brunner J., Müller T., Songer M. 2005: Forest cover change patterns in Myanmar (1990-2000). Environmental Conservation, 32: 356-364.

Mengue-Medou C. 2002: Les aires protégées en Afrique: perspectives pour leur conservation. VertigO - la revue électronique en sciences de l'environnement [En ligne], Volume 3 Numéro 1 | avril 2002, [En ligne], mis en ligne le 01 avril 2002. URL : http://vertigo.revues.org/4126. Consulté le 25 novembre 2010.

Millogo-Rasolodimby J. 2001: L'homme, le climat et les ressources alimentaires végétales en période de crise de subsistance au Burkina Faso. Thèse de Doctorat d'état, Université de Ouagadougou, $250 \mathrm{p}$.

Munsi M., Areendran G., Joshi P.K. 2012: Modeling spatio-temporal change patterns of forest cover: a case study from the Himalayan foothills (India). Reg Environ Change. DOI 10.1007/s10113-011-0272-3

Okayasu T., Okuro T., Jamsran U., Takeuchi K. 2010: Impact of the spatial and temporal arrangement of pastoral use on land degradation around animal concentration points. Land Degradation \& Development: 21: 248-259.

Vaidyanathan S., Krishnaswamy J., Kumar S. N., Dhanwatey H., Dhanwatey P., Karanth U. K. 2010: Patterns of tropical forest dynamics and human impacts: Views from above and below the canopy. Biological Conservation, 143: 28812890.

Yang J., Peter J., Weisberg P.J., Bristow N. A., 2012: Landsat remote sensing approaches for monitoring long-term tree cover dynamics in semi-arid woodlands: Comparison of vegetation indices and spectral mixture analysis. Remote Sensing of Environment 119: 62-71. 